\title{
Effect of PilE4 of Francisella tularensis subsp. holarctica (live vaccine strain) to brain endothelium
}

\author{
E Bencurova ${ }^{1 *}$, R Mucha $^{2}$, L Pulzova ${ }^{1}$, M Bhide ${ }^{1,2}$ \\ From The 1st Conference on Neglected Vectors and Vector-Borne Diseases (EurNegVec): with Management \\ Committee and Working Group Meetings of the COST Action TD1303 \\ Cluj-Napoca, Romania. 8-11 April 2014
}

Francisella are rare, highly infectious vector-borne bacteria, which infect more than 250 host species, including humans. Francisella are able to invade multiple organs in the host body, such a skin, liver, lung and central nervous system. To invade various organs, Francisella have to cross the cell linings like endothelial barriers. Interaction with endothelial cells is multistage process, which includes adhesion and activation of signaling events. Our previous work has shown that Francisella tularensis subsp. holarctica Live Vaccine Strain (LVS) interacts and adhere to endothelial cells through PilE4 and Intercellular adhesion molecule 1(ICAM-1) interaction. To corroborate consequences of PilE4 adhesion to endothelial cells, we incubated brain microvascular endothelial cells with recombinant PilE4 protein and assessed the regulation of several genes with qRT-PCR. Results showed that PilE4 upregulated the expression of adhesion molecules (ICAM-1 and PECAM-1), matrix metalloproteases (MMP 1, MMP 3 and MMP 9) and molecules that are involved in pathogen recognition (TLR-6, MyD88, IRAK-1 and TRAF6) in brain endothelium. On the other hand, we found down regulation of interleukins and NF-kB. Inhibition of NF-kB indicates that Francisella might use NF-kB subversion mechanism to evade immune response. This mechanism is described in other pathogens such as Listeria and Yersinia. Previous studies have showed that matrix-metalloprotases, mainly MMP-9, is crucial to disrupt cytoskeleton of brain endothelium to increase the permeability of BBB. In summary, work reveal hidden aspects of invasion and translocation of Francisella across the brain

\footnotetext{
* Correspondence: elena.bencurova@uvlf.sk

'Laboratory of biomedical microbiology and immunology, University of

veterinary medicine and pharmacy in Kosice, Kosice, Slovakia

Full list of author information is available at the end of the article
}

endothelium, that offers new insight into the pathobiology of neuroinvasion of Francisella.

\begin{abstract}
Acknowledgements
This work was supported by APW-0036/10, VEGA-1/0054/12 and structural funds for centers of excellence-26220120002 (INFEKTZOON). E.B and L.B. are funding for post-doctoral studies from ITMS 26220220185.
\end{abstract}

\section{Authors' details}

'Laboratory of biomedical microbiology and immunology, University of veterinary medicine and pharmacy in Kosice, Kosice, Slovakia. ${ }^{2}$ Institute of Neuroimmunology, Slovak Academy of Science, Bratislava, Slovakia.

Published: 1 April 2014

doi:10.1186/1756-3305-7-S1-P10

Cite this article as: Bencurova et al:: Effect of PilE4 of Francisella tularensis subsp. holarctica (live vaccine strain) to brain endothelium. Parasites \& Vectors 2014 7(Suppl 1):P10.

Submit your next manuscript to BioMed Central and take full advantage of:

- Convenient online submission

- Thorough peer review

- No space constraints or color figure charges

- Immediate publication on acceptance

- Inclusion in PubMed, CAS, Scopus and Google Scholar

- Research which is freely available for redistribution

Submit your manuscript at www.biomedcentral.com/submit
() Biomed Central 